DOI https://doi.org/10.30525/978-9934-588-90-7-53

\title{
МЕЖДИСЦИПЛИНАРНЫЙ КОНСТРУКЦИОНИСТСКИЙ ПОДХОД К ИЗУЧЕНИЮ ИДЕНТИЧНОСТИ
}

\author{
Матузкова Е. П. \\ доктор филологических наук, \\ профессор кафедры теории и практики перевода \\ Безпалова Е. В. \\ кандидат филологических наук, \\ доцент кафедры теории и практики перевода \\ Одесский национальный университет имени И. И. Мечникова \\ г. Одесса, Украина
}

В становлении идентичности как научного понятия на протяжении XX-XXI веков можно выделить четыре этапа: I этап: 1900-1960 артикуляция понятия; II этап: 1960-1980 - актуализация понятия; III этап: 1980-2000 - универсализация понятия; IV этап: 2000 - по настоящее время - категоризация понятия (об этом подробнее см. [5]).

Четвертый этап характеризуется категоризацией понятия «идентичность» в научном знании и окончательным закреплением за ним междисциплинарного статуса. Четко обозначившиеся «магистральные» направления в изучении идентичности связаны с разработкой ряда проблем: идентичность и идентификация, идентичность и социум (социальная идентичность), идентичность и группа (коллективная, групповая идентичность), идентичность и нация (национальная идентичность), идентичность и этнос (этническая идентичность), идентичность и культура (культурная идентичность), идентичность и пол (половая, гендерная идентичность), идентичность и виртуальное пространство, идентичность и язык. Данные проблемы, наряду с особо актуальными на этом этапе вопросами классификации идентичности по структурно-системным параметрам, разрабатываются в русле ведущиих междисциплинарных научных подходов к изучению идентичности: психоаналитического, социологического, когнитивного и конструкционистского.

В XXI веке большинство исследований идентичности в социогуманитарной парадигме связаны с чрезвычайно актуальными проблемами межгрупповых отношений. Поэтому развивающееся в предшествующее столетие в рамках когнитивного подхода конструкционистское направ- 
ление, в котором основное внимание уделяется именно этому аспекту идентичности и которое базируется на концепции конструктивного альтернативизма Дж. Келли и теории персональных конструктов (В. Брушлинский; Е. Головаха; М. Дуглас; Дж. Келли; Ф. Франселла и др.), получает всё более широкое распространение. Это способствует тому, что в современной гуманитаристике конструкционистская (конструктивная) модель анализа идентичности получает статус самостоятельного (хотя и тесно связанного с когнитивным) междисциплинарного подхода к исследованию идентичности. Данный подход, по мнению ученых, позволяет более полно выявить механизмы формирования и трансформации идентичности в условиях современного общества, роль самой личности в создании определенных идентичностей, а также точнее описать социальный уровень определения идентичности, поскольку понятие «личностный конструкт» отражает внутреннюю солидарность человека с социальными, групповыми ценностями и тем самым помогает процессу категоризации «Я» с помощью языковых знаков [3;4;6; 9 и др.].

В работах данного подхода изучаются механизмы самоопределения личности через принадлежность к социальной категории; сущность, механизмы формирования и структура социальной идентичности как производной процесса конструирования социального мира; этническая идентичность как один из ключевых социальных конструктов и многие другие вопросы (Г.Андреева; Н. Иванова; И Киселев; Т. Мищенко; Т. Румянцева; А. Смирнова; Т. Стефаненко).

Главными объектами этих исследований являются социальная группа и личность как представитель этой группы, но в отличие от других подходов проблематика идентичности рассматривается в несколько ином ракурсе. Во-первых, анализируются возможности конструирования различных видов социальной идентичности (профессиональной, семейной, этнической и т.д.) для анализа социальнокультурного становления личности. Во-вторых, идентичность объясняется с точки зрения развития самого индивида в результате языкового конструирования системы ценностей на основе понимания своего места в социальном мире. Социальная идентичность выступает здесь не только как одна из форм отражения социальной реальности, но и как производная процесса конструирования социального мира. Под конструированием понимается систематизация информации о мире, организация этой информации в языковые связные структуры с целью постижения ее смысла. Таким образом, подчеркивается «активность познавательной деятельности субъекта в ходе построения идентификационной структуры» [1]. 
В этом контексте идентичность (социальная прежде всего) рассматривается как важный компонент самосознания, образа-Я, как динамическая система конструктов, составляющая ядро личности и отражающая смысловые и оценочные представления человека о самом себе как члене социальных общностей. Формирование и функционирование идентичности обеспечивается двумя взаимосвязанными процессами: познанием группы и познанием самого себя $[1 ; 2 ; 3]$.

Основными функциями идентичности при этом являются не только адаптация к социальному пространству, но и структурирование опыта, конструирование реальности - индивид строит гипотезы, взвешивает, оценивает данные опыта и несовпадение индивидуальных мнений, систематизирует факты, то есть интерпретирует, конструирует реальность, создавая свои системы языковых конструктов. Все это необходимо ему для успешной ориентировки в социальном пространстве, особенно в современных условиях подвижных и стремительных изменений, когда приходится быстро сопоставлять индивидуальные качества с требованиями новой группы/групп.

В конструкционистском подходе все чаще, наряду с терминами «развитие», «формирование», «конструирование» идентичности используется более современный термин - «трансформация» идентичности, который включает все предыдущие, поскольку означает преобразование, превращение, изменение структуры идентичности под влиянием различных факторов, как возрастных, так и социальных. В большей степени, чем остальные, он применяется по отношению к быстрому изменению и конструированию идентичности под влиянием социальных факторов нестабильности и неопределенности, социокультурных перемен и смены политического устройства общества [6] и межнациональных конфликтов и национальных революций («оранжевая», «революция тюльпанов», «революция роз», «арабская весна» и т.д.).

Как и в когнитивном подходе, основными механизмами идентичности в конструкционистском подходе считаются сопоставление, сравнение с другими, социальная категоризация.

Идентичность, таким образом, определяется как центральный смыслообразующий элемент личности, имеющий когнитивно-аффективную природу и оказывающий влияние на ценностно-смысловую сферу языка, мышления и поведения человека. Социальная идентичность при этом выступает как целостная динамическая система ключевых социальных конструктов личности, создаваемая (конструируемая) субъектом при пересмотре своего места в социальной среде, в ходе взаимодействия, социального сравнения и являющаяся когнитивно-мотивационным 
основанием восприятия индивидом новых социальных ценностей $[1 ; 3 ; 6 ; 7 ; 8]$. По нашим наблюдениям, в относительно унифицированных определениях идентичности в рамках конструкционистского подхода синтезируется эволюция основных положений всех рассмотренных выше подходов к изучению идентичности. Это позволяет рассматривать конструкционистский подход как ведущий методологический вектор современной теории идентичности.

Заключая краткий теоретический обзор ведущих междисциплинарных подходов к изучению идентичности, отметим, что идентичность как сложный и многогранный феномен получает многочисленные и разнообразные интерпретации в каждом из этих подходов. Это иллюстрирует до сих пор нерешенную, «глобальную» проблему общей теории идентичности, связанную с выработкой унифицированного, терминологически четкого, схематически выверенного и ясного определения идентичности в рамках каждого из описанных подходов.

\section{Литература:}

1. Андреева Г.М. Психология социального познания М., 2000. 216 с.

2. Иванова Н.Л. Социальная идентичность и профессиональное становление личности: Монография. Ярославль: Изд-во МАПН, «АспектПресс», 2005. 135 c.

3. Иванова Н.Л., Румянцева Т.В. Социальная идентичность: теория и практика. М. : Изд-во СГУ, 2009. 453 с.

4. Келли Д. Теория личности. Психология личностных конструктов. Перевод и научная редакция А.А. Алексеева. СПб, 2000. 104 с.

5. Матузкова Е. П. Идентичность и лингвокультура: методология изучения: монографія. Одесса: Издательство КП ОГТ, 2014. 333 с.

6. Стефаненко Т.Г. Социальная и этническая идентичность. Идентичность: хрестоматия. Воронеж: Изд-во Моск. психол-социал. института: МОДЭК, 2003. С. 196-220.

7. Стефаненко Т.Г. Этнопсихология. М.: Институт психологии РАН, «Академический проект», 1999. 320 с.

8. Bauman Z. Identity. Conversations with Benedetto Vecchi . Polity Press, Cambridge. 2010. 104 p.

9. Mišić Ilić B.I., Lopičić V. Exploring Identity // Identity Issues: Literary and Linguistic Landscapes. Cambridge Scholars Press, 2010. P. ix - xvii. 